\title{
Interaction of Music as a Soft Power in the Dimension of Cultural Diplomacy between Indonesia and Thailand
}

\section{Surasak Jamnongsarn}

Department of Music Education, Faculty of Fine Arts,

Srinakharinwirot University, Bangkok, Thailand. Email: temanbkk@hotmail.com

\begin{abstract}
The phenomenon of cultural diplomacy between Indonesia and Thailand had appeared since the visit of the Kings of Thailand to Java more than a hundred years ago. In addition, the Indonesian immigrants who has come to Thailand are also an important factor of musical history of both countries. As a result of these interactions, the exchange of ideas, information, value, system, tradition, belief, and other aspects of culture are in the interest of foster mutual understanding through musical dimension. More precisely, the interaction contributes to the exchange of musical ideas. In the Thai music history, angklung and gamelan is an essential tool for building international relations between the two countries at the community level.

The relation between the two countries is similar to the relationship between two people so that emotion is the key methodologies in cultural diplomacy. The purpose of diplomacy is to give those people around you to know you better. There used to be a lot of cultural imperialism in cultural diplomacy, but this should be avoided. Currently, cultural diplomacy can give an idea on how a country engaging with others, a capacity to share and accept other viewpoints.

The music has a very positive impact for the development of musical culture in Thailand today.Angklung has been taught in every elementary school in the whole of Thailand, even at the level of junior high school and high school. The ideas of new works by Thailand composers today inspired many of the gamelan orchestra. Despite the fact may be felt by the people of Thailand that the influence of Indonesian music is so powerful, so far no Thai person who writes about the history of this music as cultural diplomacy. Cultural diplomacy conceived and built in three models of representation: soft power, nation branding, and cosmopolitan constructivism.
\end{abstract}

Keywords: Interaction of Music, Cultural Diplomacy, Angklung, Javanese Gamelan and Traditional Thai Music

\section{INTRODUCTION}

The Association of Southeast Asian Nations (ASEAN) is a large organization large area and has a colorful cultural diversity. ASEAN member countries improve cooperation in culture to establish an ASEAN identity. They are trying to promote ASEAN awareness and a sense of togetherness, preserving, and promoting ASEAN cultural heritage, 
promoting cultural creativity and industry, and being engage with the community. ASEAN leaders imagine ASEAN as a community of people who care about each other, bound with regional identities together, consciously historical ties, and realize cultural heritage.

In some ASEAN countries, cultural heritage has a co-root that strengthens friendship and diplomacy. Culture has become a valuable tool for diplomacy, especially for public diplomacy and as a soft power contributor, due to spreading cultural diplomacy distinctive national identity; growing importance of the cultural dimension of economic interests and the intrinsic cultural attractiveness to the population of globalization (Mark, 2008: ii). The principles of cultural diplomacy are: (1) Respect and Recognition of Cultural Diversity and Heritage, (2) Global Intercultural Dialogue, (3) Justice, Equality and Interdependence, (4) The Protection of International Human Rights, (5) Global Peace and Stability (Source: http://www.culturaldiplomacy.org), also as written of Sofia Kitsou in The Power of Culture in Diplomacy: The Case of U.S. Cultural Diplomacy in France and Germany:

...Cultural diplomacy is defined as the "exchange of ideas, information, art and other aspects of culture among nations and their people in order to foster mutual understanding" (Cummings, 2003). Culture, which is said to be the whole complex of distinctive spiritual, material, intellectual and emotional features that characterize a society or social group, includes not only arts and letters, but also modes of life, the fundamental human rights, value systems, traditions, and beliefs (Source: http://portal. unesco.org/culture). It consists of language, ideas, beliefs, customs, taboos, codes, institutions, tools, techniques, work of art, rituals, ceremonies, and symbols (Source: Webster's Collegiate Encyclopedia, 2000). Therefore, every culture represents a unique and irreplaceable body of values since each people's traditions and forms of expression are its most effective means of demonstrating its presence in the world (Source: http://portal. unesco.org/culture). It is similar to Ashcroft that culture is both a function and source of identity (Ashcroft and Ahluwalia, Said: 2009: 85). Language is the most salient feature of the culture of a people.

ASEAN Socio-Cultural Community (ASCC), Indonesia and Thailand are members, aims to contribute to realize the ASEAN Community, people-oriented and socially responsible. ASCC intent is to achieve enduring solidarity and unity between the people and the ASEAN member countries. This is an attempt to establish a common identity and build a caring and share community to improve the livelihoods and welfare of the public. ASCC focus on the maintenance of human resources, culture and nature for sustainable development in ASEAN harmonious and people-oriented (Source: http://www.asean.org).

Relations between the two countries is similar to the relationship between two people so that emotions are the key method in cultural diplomacy. The purpose of diplomacy is to give those people around you to know you better. There used to be a lot of cultural imperialism in cultural diplomacy, but this should be avoided. Currently, cultural diplomacy can give an idea of how a country to engage with others, the capacity to share and accept other viewpoints (Claudel, 2011: 53).

The phenomenon of cultural diplomacy between Indonesia and Thailand began to appear since the visit of the Kings of Thailand to Java more than a hundred years ago. In addition, the Indonesian immigrants who come to Thailand are also an important factor that influence musical history of both countries. As a result of these interactions, 
the exchange of ideas, information, values, systems, traditions, beliefs, and other aspects of culture is in order to foster mutual understanding through musical dimensions. More precisely, the interactions contribute to the exchange of musical ideas. In the Thai music history, angklung and gamelan are essential tools for building international relations between the two countries at the level people to people.

\section{RESEARCH METHODOLOGY}

Figuring out the research questions and objectives as mentioned above need appropriate research techniques in accordance with the approaches used.

As a qualitative research, this research is going to reveal the textual and contextual meanings by the way of comparative study. The kind and resource of data needed in this research are primary and secondary data. The primary data is angklung and gamelan live performances in Indonesia and Thailand; and also interview with the experts of gamelan and angklung in Java and Thailand. Secondary data is books and articles which related to the research, include VCD and DVD recording. The technique of collecting data is field study and literature. Field study is related to data that collected by observation, interview, documentation, and focus group discussion. Literature research is taken to collect documents related to gamelan and angklung, and also theories used. Information and literature research can be got by the save artefact such as letter, diary, photos, archive, report, journals. Those documents are used in order to dig the past information. Researcher need to have theoretical sensitivity to interpret all of the documents.

\section{OBJECTIVE OF THE STUDY}

This study aims to describe, reveal, and identify the concepts of: 1) The interaction of music between the angklung and gamelan with background of beliefs, ways of thinking, and different music systems with traditional Thai music. 2) Processes and forms of transculturation that have occurred between gamelan, angklung and Thai music in the development of traditional Thai music, and 3) Involvement gamelan, angklung, and traditional Thai music in the process of a new national identity through music.

\section{SIGNIFICANCE OF THE STUDY}

Writing about the history of Thai and Indonesia, most historians may consider Thailand to be an important contribution on a large scale at the national or international level, and not focus on a small part of the history (micro history). Although a small part, it still has significance. The exchange or appropriation of music culture between Thailand and Indonesia in the past is one factor that contributed to the realization about common heritage in music which will support other fields of cooperation. Common heritage in music has evolved for long time with the concept of hybridization of music.

The concept of hybridisation accounted for the change, appropriation, and the idea of mixing the music. In the history of Thai music, angklung and gamelan is an important tool to create relationships with the international community, particularly 
the relationship between the two countries at the level of the people. Thai society has peculiarities, namely Buddhism for a liberal people, the absence of war (Ayodhya), the kingdom of the free, and the diverse and pluralistic people. It supports the idea of musical hybridization in Thailand and Indonesia, including the form of musical instruments, tuning system, musical concept, and a new interpretation of the music outside (Java) into traditional Thai music as the Javanese accent.

\section{Traditional Thai Music at a Glance}

Traditional Thai music which appears in its current form is identical to the repertoire and ensemble royal palace style, centers in Central Thailand, ${ }^{1}$ approximately 800 years ago. In the past, the ensembles are similar to Khmer music. Appears in its most basic formulation, the traditional Thai music assemble is similar to Cambodian (Khmer) mahori and also pinpeat assemble. It is also structurally similar to those found in other instrumentation gong-chime music culture which is widespread in Southeast Asia, such as Balinese and Javanese gamelan, which are probably likely to have the same root in the diffusion of Vietnamese bronze drum culture (Dong-Son) at the beginning of the first century. The music was very cosmopolitan, bringing the idea of the various cultures that surround it, especially Cambodia, Java, China, Burma, and so on. At that time, Thailand's musical expression is an expression of a unique, absorbing and developing musical ideas from different areas.

Traditional Thai repertoire is anonymous, names unknown composer. He inherited through oral tradition show. However, since the beginning of the modern Bangkok period, around the turn of the eighteenth to the nineteenth century, many major composers have recorded their works in notation. Musicians imagine that the compositions and notations as generic forms are realized in full idiosyncratic variations and improvisations in the context of the performance. Luang Pradit Pairoh (1881-1954) for example, used localized forms of cipher (number) notation. Other composers, such as Montri Tramote (1908-1995), used standard Baroque notation.

Thai music artists have influenced the dynamics of the development of traditional music in Thailand. They have a unique way of passing their musical traditions to the next generation. The method that run and maintained up to now is to learn music to a teacher, be a loyal followers, and play his/her composition. If a student has chosen to study to a teacher, a student should not be moved to another teacher learning. Music teacher in Thailand is also a composer who has the particularity to be his style. Distinctiveness and style song of a teacher would be a "secret" ${ }^{2}$ along to their students as a strength to compensate for and offset by teachers and other groups. It then became a tradition of competition until now.

1 What we called "traditional Thai music" is a music that is influenced by royal palace and spread across this country. In Thailand, the term of folk music is known for non- traditional Thai music, or music that lives in out of centre Thailand or in the periphery of Thailand, such as in North Thailand (in Chiang Mai and Chiangrai), Northeast Thailand (in Kon Kaen and Roi Ed), and South Thailand (in Pattalung and Songkla).

2 In the Thai traditional music culture, this style is like a game. The new generations have to play the game and should be able to solve or get out of the game or "secret" with a key by themselves. That is, if someone is able to get through or find the key, he gets the authority to make the song a new style or another style. If you have not been able to find the key, the song's creation in a teachers will last a long time. There are many traditions of music teachers in Thailand who have such capabilities. 


\section{Interaction of Music between Indonesia and Thailand in the Dimension of History}

Phenomenon of Indonesian musical influences in music history Thailand has eluded observations of Thai historian. The historians are more interested in the field of national, political, religious, and so forth. Meanwhile, the music has a positive impact for the development of culture in Thailand today. Angklung has been taught in every elementary school in the whole of Thailand, even at the level of junior high school and high school. The ideas of new works by Thai composers today are inspiring many of the gamelan ensemble. The people of Thailand said that the influence of Indonesian music is so powerful, but so far no Thai person who wrote about the history of this music as cultural diplomacy. Cultural diplomacy conceived and built in three models of representation: soft power, nation randing, and cosmopolitan constructivism ${ }^{3}$.

Traditional Thai music experiencing growth through interaction with the inclusion of variety of concepts and materials of music from other nations, such as China, Myanmar, Khmer, Eropa (Barat), and Jawa. ${ }^{4}$ Interaction between Thai and Indonesian musical tradition has been proven by the inclusion of musical instrument angklung from West Java by using the concept of Javanese gamelan. The existence of angklung by using the concept of gamelan in Thailand that have played more than a hundred years did not forget the origin of Java, so the music played by the angklung called the "Lagu Jawa (Song of Java)".

Angklung and gamelan are important music in the relation between Indonesia and Thailand, especially cooperation between the two countries. Gamelan is learned in college campuses that have a tradition of music program. In this case, Luang Pradit has greatly contributed to the popularity of Javanese music at college campuses in Thailand.

Angklung in Thailand is currently very popular among young people, schools in Thailand, especially elementary school students, as well as government and private institutions. In addition to learning, angklung also contested, recorded, performed in various events. Development of angklung form has also performed in a variety of

3 The main issues these representational models address have to do with how culture is represented abroad by diplomacies in terms of contents and discursivity, paying particular attetion to the identity-alterity relations between the cultural-real and the represented-referent. There are three fields of Cultural Diplomacy: Cosmopolitan Constructivism, Nation Branding and Soft Power. these are, more specifically: Soft power is a concept to describe the ability to attract and co-opt rather than coerce, use force or give money as a means of persuasion. In recent days the term has also been used in changing and influencing social and public opinion through relatively less transparent channels and lobbying through powerful political and non-political organizations. Nation branding aims to measure, build and manage the reputation of countries. Some approaches applied, such as an increasing importance on the symbolic value of products, have led countries to emphasise their distinctive characteristics. The branding and image of a nation-state "and the successful transference of this image to its exports - is just as important as what they actually produce and sell. Nation Branding can be approached in academics as a field in social sciences, political sciences, humanities, communication, marketing and international relations. Cosmopolitan Constructivism and Cosmopolitanism is traditionally associated with a straightforward idea: the willingness to be part of a society of nations and participate in its welfare, on material, institutional or moral grounds. This simple account is not self-evident for most nations, or for some types of diplomacies and diplomats. Cosmopolitanism's simple premise is to live and let live, understand and be understood, show respect and enjoy respect in return. Cosmopolitanism has three parts: multilateralism, pluralism and reflexivity.

4 The word "Jawa" in Thailand refers to everything that comes from Indonesia, especially those associated with music and language. 
shapes and how to play. All of it is an effort made by the people of Thailand to adjust the angklung music culture and tastes of the local community.

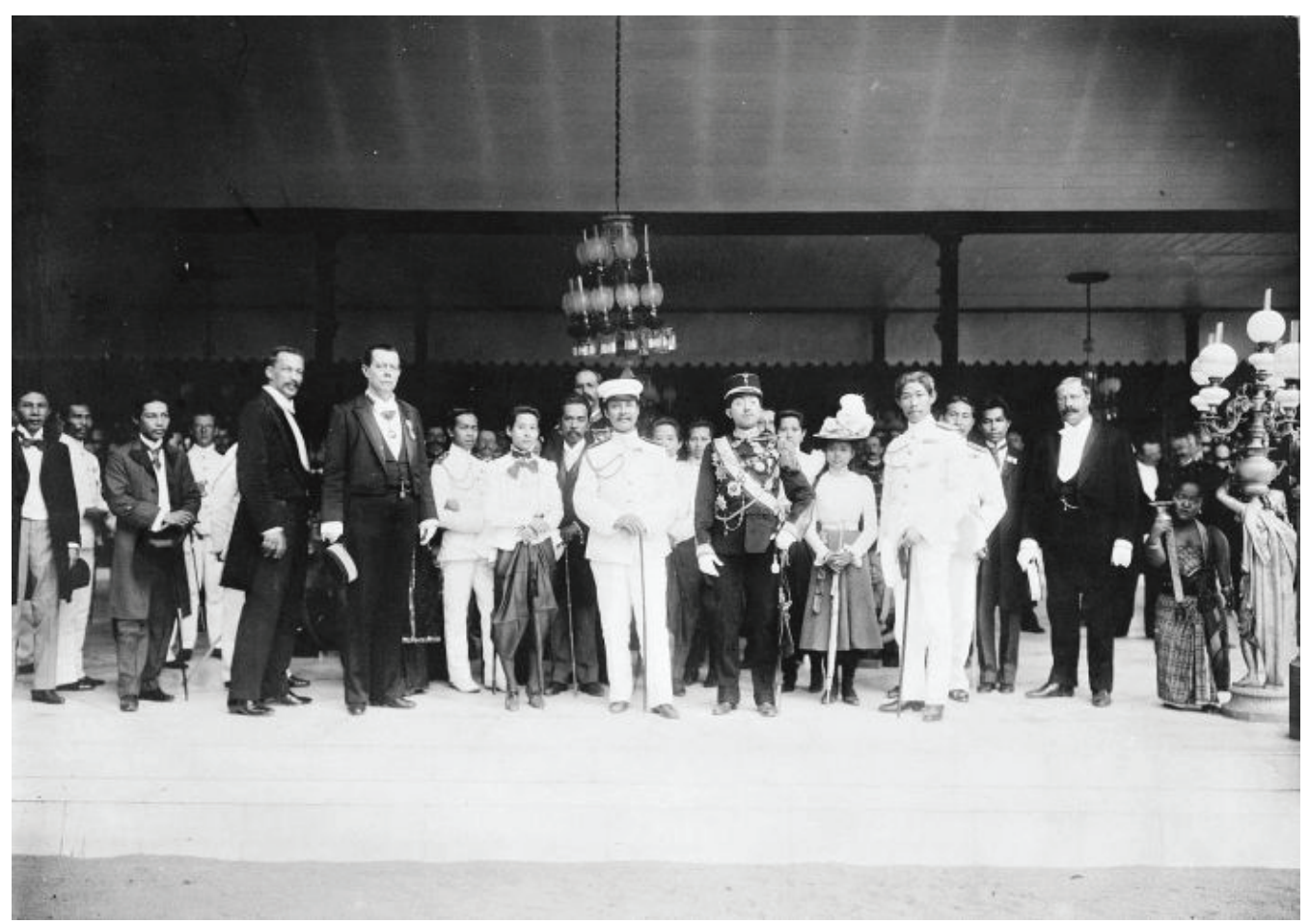

Figure 1. Pakubuwana $X$ (military uniform) and King Chulalongkorn of Thailand, in the Journey to Java, 1896 (Photo: KITLV, in Journey to Java by a Siamese King, 2012).

The spreading of angklung and gamelan music to Thailand can be known from the historical record of the Thailand Kings visit to Java. One of the information that can be traced is through recording of the visit of His Majesty the King (H.M.) Chulalongkorn or Prabat Somdet Chulachomklao (Rama V) as written in Serat Saking Gotek, Volume $\mathrm{VI}^{5}$ :

In $1896 \ldots$

...Panembrama nalika rawuhipun Sri naranata ing nagari Siyam, Kitha Bangkok, ingkang ajejuluk Sang Maha Silalon Prabu Koren Praculasom Klowa. Rawuhipun ing Surakarta amarengi ing dinten Senen Pon, tanggal kaping 25 wulan Sura ing warsa Jimakir angka 1826 (1896).

In 1901

... Sri Minulya (ladrangan) raras slendro pathet sanga. Mengeti rawuhipun sri naranata ing Nagari Siyem (raja Siyem rawuh ingkang kaping kalih) dhumateng ing Karaton Surakarta. Jelukipun Sri Maharaja Siyem wau Somdhet Prabat Paramendro; Mahasilalon Prabu Koren Praculasomklowa. Asung pratandhaning sih bintang Groot Kries Kroon Order ing Siyem. Amarengi ing dinten malem Akad Pahing, tanggal kaping 11 Mulud ing tahun Dal 1831 wuku sinta, utawi kaping 30 Juli 1901.

It said that during the visit of His Royal Highness (H.R.H.) Bhanurangsi Savangwongse, Prince Baripatra and the troupe in 1908, angklung music was brought to Thailand and developed by Luang Pradit Pairoh (his real name is Sorn

5 The Javanese gamelan musical archives, especially Surakarta palace gamelan compositions, in title: Serat Sujjarah Utawi Riwating Gamelan Wedhapradangga (Serat Saking Gotek) by R. Ng. Pradjapangrawit (1990). 
Silapabanleng). Angklung was first performed at the Rajathiwat temple in Bangkok in the royal ceremony with the form of a concert by Luang Pradit Pairoh along with his students. He created a song 'Yawa Kao' (Old Java) from the concept of Ladrang Bima Kurda (Hughes, 1992). Surakarta or Ladrang Liwung Yogyakarta for Royal Angklung Ensemble. It is also mentioned, through the song, he wanted to show the Thai people that the piece is derived from Java.

On the visit of His Majesty the King (H.M.) Prajadhipok (King Rama the $7^{\text {th }}$ ) in Surakarta, Central Java, was shown for the first time using a gamelan composition 'Ladrang Siyem'. This composition is the work of Kangjeng Wiryadiningrat, Raden Ngabehi Atmamardawa, Raden Ngabehi Wirapradangga, and Mas Lurah Reksapangrawit influenced by Thailand royal anthem song: Sanrasoen Phra Barami. This piece was created to celebrate and honor the arrival of the H.M. Prajadhipok to Surakarta palace during the reign of Paku Buwana X. Paku Buwana X also provided a set of gamelan to the king of Thailand. This gamelan was then the first in Thailand, as it is written in Serat Saking Gotek Jilid VI by R.Ng. Pradjapangrawit (Pradjapangrawit, 1990: 154).

... Ladrang Siyem (2), Slendro pathet nem. Pengetan nalika katamuan Sang Maharaja Prabu Yadipa Sukadhaya Ingkang Kaping VII, narendra Nagari Siyem, sakaliyan prameswari. Amarengi ing dinten melem Rebo Kliwon, tanggal 29 Mulud Ehe 1860. utawi 3-4 September 1929. Ladrang Siyem wau anggitan: 1. Kangjeng Wiryadiningrat; 2. Raden Ngabehi Atmamardawa; 3. Raden Ngabehi Wirapradangga; tuwin 4. Mas Lurah Reksapangrawit (Mlayaresaka).

In 1932, His Royal Highness (H.R.H.) Baripatra Sukhumbhand (Prince of Nakhon Sawan) went to Bandung after the political change in Thailand. He lived in the house that is named Praseban, ${ }^{6}$ in Cipaganti, Bandung until his death in 1944. Despite the political turmoil in Thailand has been completed, Prince Baripatra, who is also the famous composer of Traditional Thai music and western music, did not return to Thailand. While living in Bandung, he conducted a variety of music activities, including arranged many songs and sent them to Thailand. In addition, he also wrote a book about traditional Thai music notation, printed and published in Bandung which had a printing technology that more advanced than in Thailand. H.R.H. Baripatra had also sent some gamelan instruments to Thailand (Sittitanyakit, 2004).

The visit of H.M. Chulalongkorn (Rama V) (Suharto, Pattajoti, 2012) , H.M. Prajadhipok (Rama VII) ( Pradjapangrawit, 1990: 154), H.R.H. Bhanurangsi ${ }^{7}$, and H.R.H. Baripatra (Prince of Nakhon Sawan) ${ }^{8}$ to Java is an assumption about the interaction of Indonesia and Thailand music, as well as the discovery of the first gamelan musical instruments in Thailand are saved in the Department of Fine Arts and national museum, Thailand. Another proof can be seen in the form of the gamelan music in Suan Phakkaad ${ }^{9}$ and the Indonesian Embassy in Bangkok. ${ }^{10}$

6 Praseban is one of the 3 other houses in the complex. Name the other three are Dahapati, Pancarekan, and Setaman. Praseban is now kinder garden school.

7 The musicians in Thailand know that Bhanurangsi was to Java with Luang Pradit Pairoh.

8 Paladisai, 2004.

9 This gamelan is the legacy H.R.H. Baripatra Sukhumbhand, now in Suan Phakkaad palace which became a museum in the center of Bangkok.

10 This Javanese gamelan Surakarta model is approximately 50 years old in the Embassy in Bangkok. 
Thai people are still playing the old songs from Indonesia, using angklung and gamelan, as well as with traditional Thai music ensemble. For example, the song 'Burung Kakaktua' played in the musical traditions of phiphat, while the song 'Hom Rong Shawa' or 'Yawa' (Java) which included the song 'Busensok' (Buitenzorg), 'Yawa', 'Kerath Raya', 'Semarang', 'Bukan Tumo', and 'Kediri' which is played with the angklung.

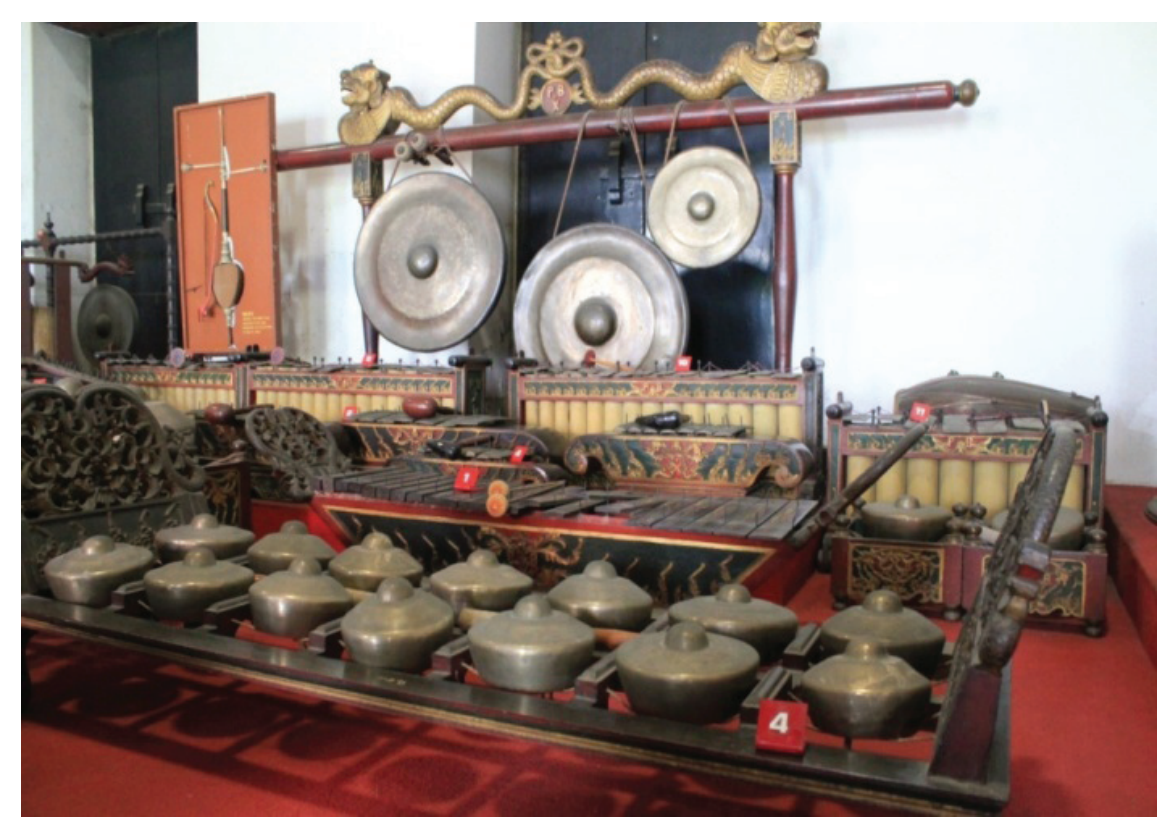

Figure 2. A set of first gamelan in Thailand from P.B. X Surakarta at the Pra Nakhon National Museum, Bangkok (Photo: Surasak, 2012).

For Thailand musicians, gamelan and angklung is representative of Indonesia, with the term "Java" inherent. Angklung is an instrument that can be touched (tangible source), while the concept of gamelan music used is not able to be touched (intangible source). Artist and composer who composed song for angklung with the concept of gamelan is Luang Pradit Pairoh. Luang Pradit more emphasized on the Javanese accent heptatonic scales. ${ }^{11}$ Concept of Javanese song is not only used for angklung, but also used for music ensembles phipat and Krueng sai (string ensemble) by other musical figures. Thai musicians developed the concept of the Javanese music with their own interpretation.

\section{Efforts to Recognize Indonesian in Lyric of Thailand Song}

Since 1900, the Thai music has often adopted the tone (accent) of music from outside Thailand. In the show, the music often uses foreign languages, such as Myanmar and dialect songs sung in Myanmar. Same with Javanese accent, the song will be sung in the Javanese language12. However, because of the limitations of language in lower

11 Thai Full Tone Heptatonic Scale is a seven equidistance system but Thai traditional song is based on pentatonic scale, there are five primary tones - 123 56, two secondary tones - the scaled degree 4 and 7.

12 It is Indonesian language, but for Thai people it is mean Javanese language: The word "Jawa" in Thailand refers to everything that comes from Indonesia, especially those associated with music and language. 
tracks from generation to generation by oral tradition actors, forms and meanings are always shifting and may be not the same as the original. Owner language no longer understand what is delivered even ask, "Is it my language?" Here is an example of a song called 'Kediri' presented by the Thai composer:

Lyric

มินตะบะลิตวนอา ดะซารามัด ดะซารามัด ซัมปาราน mintabe ri tuan-a da selamat da selamat samparana

สะโห ปาตี ปาตี บารังอินี อังกัสตาปา

saho pagi pagi barang ini angkat setapa

Melodies:

\begin{tabular}{|c|c|c|c|c|c|c|c|}
\hline - - - & - - - & - D R D & R F R F & $-\ldots S$ & - L - - & $-D-R$ & - F- S \\
\hline D R F S & - - - & -FR D & RF R F & $-\cdots S$ & - L - - & $-D-R$ & - F- S \\
\hline - - - D & $-\cdots$ L & $--S$ & - F - - & - RF S & LRF S & - F- R & $D L-D$ \\
\hline$-\ldots$ D & -- - L & $--S$ & $-F-$ & - RF S & LRF S & - F- R & $D L-D$ \\
\hline
\end{tabular}

Thai musicians are trying to find an answer why Indonesian people do not understand the songs they sing. They guessed that the answer might be the song that they sing is no longer the same as the original song, or because the ancients did not present it in writing but orally, is also not known who created the songs they sing.

I am, as a Thai musician who likes Indonesian, Indonesian angklung, Javanese gamelan, and Indonesian language, assuming that there are several possibilities:

1. People who created the songs did not understand Indonesian, but wanted to write a song using Indonesian language.

2. The person who created the song, first of all write the songs with Thai language, then translate it into Indonesian with the help of a dictionary but with the word-by-word.

The important evidence is the Dictionary Thai-Malay written by Pan Sae Ko in 1936 (Angklung and the angklung songs began to spread in Thailand after 1925). It was a sentence written in the preface of dictionary, which is: to be used in communicating with the Malays as in Singapore, Penang, Kuala Lumpur, Alor Setar, Ipoh, and Java.

Using of Indonesian in the structure of the Thai language in 'Kediri' is an example of the song. The words "selamat jalan atau selamat tinggal" spoken by the people of Thailand with "Kho hai khun mi kwam suk". Those words were said congratulation generally passed to others when it would split that equated with English "have a nice davs or good luck".

Most likely, some used vocabulary in Indonesian and Malay dictionary with word by word, but did not quite understand the Indonesian language format and grammar, which resulted in different meanings. 


\section{"Mintabe Rituan-a Dasalamat Dasalamat Samparana"}

The words referred:

"minta beri tuan ada selamat ada selamat sampurna"

("asking to give master/ here is safe/ here is safe /perfect")

What happened? The answer is because the person who coined the phrase wanted songs in Thai as:

"Kho hai khun mi kwam suk"

Whereas:

"kho = minta (ask), hai = beri (to give), khun = tuan (master), mi = ada (is), and kwam suk= selamat (safe)

When singing a song that was created in accordance with, giving pause or stop point, into: "Mintabe Rituan-a Daselamat Daselamat Sampurna".

Differences in terms of language (syllables) are not so different, the occurrence of the long-time, or a notice from oral tradition, but also occur because of sentence structure (preparation of syllables) which from the first has not been true yet. Key to understand this is a "dictionary and how to acquire vocabulary". Now anyone who reads this simple writing will understand why Indonesian people do not understand the "Indonesian language". When asked by the Thai people, they can not give a definite answer because the people of Thailand and Indonesia are both "lied" primary source of a "fact", not "truth". Fact in this case is a syllable, for example in the song Kediri, which is composed in such a way as not to form meaningful sentences. Truth happens when the "secret" was revealed that the arrangement of syllables that form a meaningful sentence.
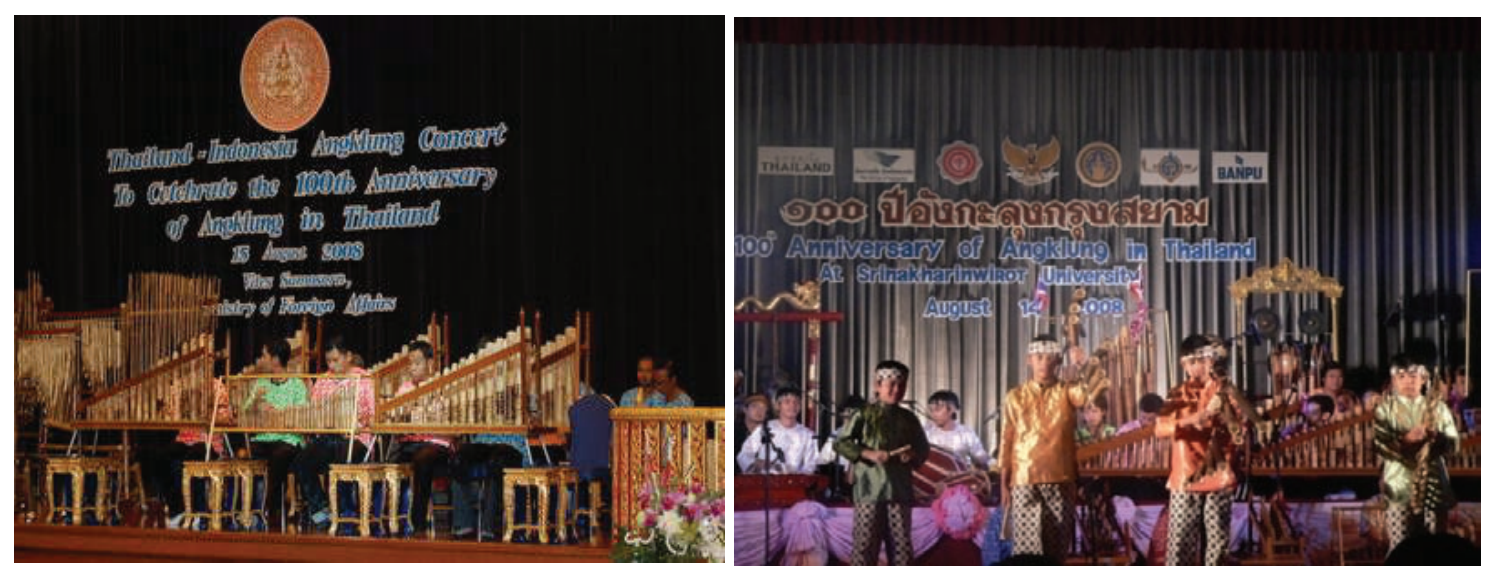

Figure 3 and 4. Photos 3-4, the Centenary Anniversary of Indonesian Angklung to Thailand, 2008 at Srinakharinwirot University and Ministry of Foreign Affairs of Thailand (Photo: resource of Department of Music Education, Srinakharinwirot University, 2008).

In 2008, there was a grand celebration at Bangkok, Thailand, to mark the $100^{\text {th }}$ anniversary of the introduction of angklung to Thailand that organized by both the Thai and Indonesian governments included Ministry of Foreign Affairs Republic of Indonesia and Kingdom of Thailand, the Embassy of Republic of Indonesia, Bangkok, 
the Foundation of Master Luang Pradit Pairoh, and Srinakharinwirot University. The $100^{\text {th }}$ anniversary of the angklung to Thailand was confirmed that the soft power has played a role positively in any diplomatic negotiation remains dependent on the nature of the power relationship, shared values and culture amongst other things. When music culture is viewed as a resource, capital, and power, national cultural identity becomes a significant policy concern. Culture is thus both a commodity as well as means of social transformation. The multi-dimensional process of cultural diplomacy is assessed through two paradigms of national agendas: socio-political and economic. The first socio-political paradigm of national interest is benchmarked by soft power. In case of Indonesia and Thailand, traditional music especially angklung and gamelan serves as an important aspect of successful bi-lateral and multi-lateral diplomacy and consequently requires a holistic conceptual framework for sound pragmatic implications.

\section{CONCLUSION}

In conclusion therefore, soft power in isolation does not seem to dominate in its importance in diplomacy. Also the music interaction between Indonesia and Thailand does not seem an importance in diplomacy but without cultural claim or disclaim problem because we make more cultural understanding between us through music in dimension of a cultural diplomacy which is soft power as a tool.

Most of Thai historians prefer to consider an important contribution to a larger scale in the national and international level than a small part of the history (micro history). For example writing about history of Thai music; a small part, but still has significance in Thailand. However, the relationship at the level people to people that is built up of music, has so far avoided conflict between Indonesia and Thailand.

ASEAN Community 2015 would also be good if supported by the music, because the relationship through music as cultural diplomacy has been happening long time ago. Under these conditions, the authors were challenged to write history of this music as an important contribution to the history of Thai music as cultural diplomacy between Indonesia and Thailand that have long shared heritage as a tree whose root joint (coroot) such as Javanese gamelan, angklung, and traditional Thai music.

\section{REFERENCES}

Ashcroft, Bill and Ahluwalia Pal. (2009). Edward Said. 2nd ed. London: Routledge. Claudel, Sophie. (2011), Brunswick Review, Issue 4. Summer, London: UK.

Cummings, Milton C. (2003). Cultural Diplomacy and the United States Government: A Survey. Washington, DC: Center for Arts and Culture.

David W, Hughes. (1992), Thai music in Java, Javanese music in Thailand: Two case studies, British Journal of Ethnomusicology. Volume 1, Issue 1: London.

Kongchana, Plubplung. (2011), Learning and Historical Evidence Process, Bangkok: Sukhothai Thamathirat University Press.

Kunst, Jaap. (1959), Ethnomusicology [3rd Edition], The Hague: Martinus Nijhoff. Mark, Simon. (2008), A Comparative Study of the Cultural Diplomacy of Canada, New Zealand and India, Ph. D. in Political Studies Thesis, the University of Auckland: New Zealand. 
Merriam Webster's Collegiate Encyclopedia. (2000), s.v. “culture”.

Mloyowidodo, S. (2013), Gending-Gending Jawa Gaya Surakarta, -, - -

Mrazek, J. (2008), Xylophones in Thailand and Java: A Comparative Phenomenology of Musical Instruments, Asian Music, 39(2), 59-107.

Phuaksom, Thaweesak. (2004), Indonesia Raya: Traditional State to Imaginations Country, Bangkok: Muang Boran.

Pradjapangrawit, R. Ng. (1990), Serat Sujjarah Utawi Riwating Gamelan Wedhapradangga (Serat Saking Gotek), Surakarta: STSI Surakarta and Ford Foundation.

Suharto, Imtip Pattajoti. (2012), The Journey to Java by a Siamese King (English Edition), Bandung: ITB Press.

\section{ONLINE RESOURCES}

Mexico City Declaration on Cultural Policies. World Conference on Cultural Policies. Mexico City: July 26-August 6, 1982. Accessed January 5, 2011,http://portal. unesco. org/culture/en/\#les/12762/11295421661mexico_en.pdf/mexico_en.pdf.

http://www.asean.org/communities/asean-socio-cultural-community/category/aseanministers-responsible-for-culture-arts-amca).

http://www.culturaldiplomacy.org/index.php?en_cultural diplomacy. 